\title{
LIVING IN THE POSTHUMAN NETWORK SOCIETY: MOBILITY AND SURVEILLANCE IN BLACKHAT ${ }^{1}$
}

\author{
Esther MuÑoz GonZÁLeZ \\ University of Zaragoza \\ emunoz@unizar.es
}

\begin{abstract}
Although not a box office success and with serious flows regarding narrative structure and performance, Blackhat (2015) is undoubtedly a film that shows its belonging to a specific context and historical moment: it reflects upon some of the worries, changes and consequences of the combination of new technologies and socio-political events. The purpose of this paper is to analyze the visual and aesthetic mechanisms the film uses to present firstly contemporary changes in communication and secondly present-day worries related to security and the risk society, which have triggered the expansion of surveillance systems. Finally, it will also address the ways through which this new network society affects and is the tool for the construction of new identities while it also changes our perception of reality.
\end{abstract}

Keywords: Network Society, surveillance, mobility, dataveillance, posthuman, space, flows.

This paper has been possible thanks to the funding received from the Spanish Ministry of Economy and Competitiveness (FFI2015-63506-P), the Government of Aragón and the European Social Fund (ESF, H05). 


\title{
VIVIENDO EN LA POSTHUMANA SOCIEDAD VIRTUAL: MOVILIDAD Y VIGILANCIA EN BLACKHAT
}

\begin{abstract}
RESUMEN. Sin ser un éxito en taquilla y con serios fallos en relación a su estructura y actuación, Blackhat (2015) es sin lugar a dudas una película que pertenece a un contexto y momento histórico específico: la película refleja algunas de las preocupaciones, cambios y consecuencias que la combinación de nuevas tecnologías y sucesos socio-políticos han supuesto en los últimos años. El propósito de este artículo es analizar los mecanismos visuales y estéticos de los que se vale la película para presentar en primer lugar los cambios actuales en comunicación y en segundo lugar cómo la preocupación por la seguridad y una sociedad de riesgo han propulsado la expansión de los sistemas de vigilancia. Finalmente, se centra en explicar cómo esta nueva sociedad en red influye y es el medio con el que se construyen nuevas identidades individuales y se cambia la percepción de la realidad.
\end{abstract}

Palabras Clave: Sociedad en Red, vigilancia, movilidad, vigilancia de datos, posthumanidad, espacio, flujos.

Received 7 December 2016

Revised version accepted 20 July 2017

Blackhat (2015) is a US film directed by Michael Mann and released in January 2015. It starts with a montage sequence that functions as the visual demonstration of how a malware virus is spread into a nuclear plant's computer system in China, causing an explosion and victims. A furloughed convict, Nick Hathaway - Chris Hemsworth - , together with two FBI agents and a Chinese one try to hunt the cybercriminal who has provoked the explosion, in a journey that will take them across a number of places: Chicago, Los Angeles, Hong Kong, and Jakarta. Although the film seems to "be trying to make some serious points about cyberwarfare and mass surveillance in a globalized world" (Macnab 2015: np), most critics found it disappointing (see Bradshaw 2015; Macnab 2015; O'Sullivan 2015). Although not a box office success, and with serious flows regarding narrative structure and performance, Blackhat is undoubtedly a film that overtly shows its belonging to a specific context and historical moment: it ponders on some of the worries, changes and consequences of the combination of new technologies and socio-political events. The purpose of this essay is to analyze the visual and aesthetic mechanisms the film uses to present firstly contemporary changes in communication and secondly contemporary worries related to security and the risk society, which have triggered the expansion of surveillance systems, not only at the governmental or official level but also at the particular or people-to-people 
level. In addition, this paper will also center on how this new network society affects the construction of our (post)human identity and our perception of reality, and conclude the film's concerns as going beyond mere market expectations.

It is an undeniable fact that technology and mainly the Internet have changed the way people communicate, relate to others and live. We have become a technological generation for whom digital technology, computers, e-mails, and the Internet are constituent parts of our lives. We can have face-to-face interaction with friends who live in the other side of the world; we shop online, we work through and with the web, and send good wishes, money, photos, and all kind of documents via the internet. It is people who make society and, as the sociologist Manuel Castells points out: "Technology is society, and society cannot be understood or represented without its technological tools" (2000: 5). This relatively new way of living based on communication technologies gives birth to what Castells calls "the network society" in which there are movements of people, goods and information over large distances. This is not a new phenomenon but nowadays there is a key difference with past times: they take place in real time from one end of the world to the other. This is the basis of the new spatial arrangement that Castells refers to as "the space of flows." He defines it as "purposeful, repetitive, programmable sequences of exchange and interaction between physically disjointed positions held by social actors in the economic, political and symbolic structures of society" (2000: 442). In this new state of things, we still live in the geographical space conformed by real world and time, what Castells denominates "space of places." It is the physical support in which people bodily interact and live. But localities are "disembodied from their cultural, historical, geographical meaning, and reintegrated into functional networks, or into image collage, inducing a space of flows that substitutes for the space of places" (Castells 2000: 406). In other words, one of the consequences of digital technologies is the creation of alternative realities and communities, specifically composed of data, to the extent that they become a reality that occupies a space very close to traditional physical reality. In this way, in later years the dichotomy 'real world' versus 'virtual/computerized one' has been born. The real world is experienced by what we have traditionally understood to be real time and physical/tangible space. The virtual world, on the other hand, belongs initially to a separate level, intangible and mediated and controlled by computers and other technological devices which mainly deal with information. Even though the distinction between virtual and physical seems to be clearly delimited, if the conceptualization of both of them is approached from a Posthuman perspective, this difference is not so categorical since "in the Posthuman, there are no essential differences or absolute demarcations between bodily existence and computer simulation, cybernetic mechanism and biological organism, robot 
teleology and human goals" (Hayles 1999: 3). That is, both are entangled and one is inseparable from the other, because as Hayles further contends "all material objects are interpenetrated by flows of information, from DNA code to the global reach of the World Wide Web" (1999: 15).

Nevertheless, Castells's concept of the "space of flows" constitutes a very appropriate perspective from which Blackhat can be understood since it deals with flows in a very direct and explicit manner, to the extent that throughout the film there is an alternation of shots depicting flows and shots depicting places both in the virtual and in the physical realms. The first shot in the film, the establishing shot that usually shows the location of the film, is very meaningful. It is an extreme long shot, so extreme that it is a general view of the Earth. Our planet is surrounded and covered by millions of connections, there are not any visible borders, every place appears interconnected with the rest of the world and the sound of electronic beeping and whispering voices evoke transnational communication. The next scene offers the visual definition of Castell's space of flows: the camera crosses the line between the real and the physical worlds. The camera enters the computer screen and the audience travels through it like an input, unstoppable and at dizzying speed. Without limits or borders this intangible sent order - afterwards we find out it is a malware — travels through a usually invisible space of flows and ends up with an explosion. In the next scene, sound and images are edited in a fast manner to produce a documentary aesthetic: television screen shots giving the sensation of being realistic footage. They are images that we are used to seeing when we watch the news on the television: firefighters, injured people, and ambulances. This is our physical reality, outside the computer, and the scene functions as a demonstration and reminder of how this flow of information does cause damages in the space of places. Actions in the virtual world have consequences in the tangible one, and this is for many people a real threat.

The silent presence of the 9/11 attacks has become an almost permanent imprint in the minds of many Americans causing a change in the way people live and think. The terrorist attacks have had a major impact in their collective consciousness, because they have lost the feeling of being in a safe place at home, in their country. According to the German sociologist Ulrich Beck we live in a "world risk society" that is, in a world of "uncontrollable risk [...] that does not arise from the fact that everyday life has generally become more dangerous. It is not a matter of the increase, but rather of the de-bounding of uncontrollable risks. This de-bounding is three dimensional: spatial, temporal and social" (2002: 41). For Beck, these uncontrollable risks "are not being linked to place, that is, they are difficult to impute to a particular agent and can hardly be controlled on the level of the nation state" (2002: 41). 
According to the American cognitive linguist George Lakoff, at a national level governments are the only ones responsible for the citizens' welfare and national security. He establishes a parallel between the work of the nation and a family where the government is the responsible father in charge of his citizens/children's security (2006: 50). This responsibility also seems to legitimize governments to control and police their citizens to prevent clandestine activities, that is, they ideally work towards guaranteeing the citizens' safety in every conceivable respect. In practice, it implies a constant increase in the surveillance systems, which can jeopardize the population's privacy.

New technologies have been developed to improve the efficacy and scope of surveillance systems at the same time as they have triggered enormous changes in the systems themselves. According to Gabrielidis, surveillance systems have evolved a great deal from Foucault's notion of the Panopticon that he developed in Discipline and Punish (1977), a model that was suitable to describe the need for control measures in the $18^{\text {th }}$ and $19^{\text {th }}$ centuries' disciplinary societies but that seems, to say the least, worrisome to be applied to the practices of $21^{\text {st }}$ century society (2015: 492). The Panopticon was a model of prison in which the design allowed a single watchman to see all cells and inmates at once. Parfait, quoted by Gabrielidis, explains that each inmate, acknowledging the possibility of being permanently seen, makes possible the smooth functioning of the power system without any person actually assuming the surveillance task (2015: 493). Even though the vigilant was not physically able to observe all prisoners at once, the simple possibility of being watched forced convicts to control their own behavior. More recently, Polish sociologist Zygmunt Bauman proposed the term Synopticom as counterpart to the Panopticon (1998). Instead of many being policed by few, the new technologies and digital media allow for a society in which eventually it is the many who watch the few. That is, in contrast with the Panopticon the Sypnopticon is a device not interested in the production of a docile and useful working force but in the creation of a viewer subject, a consumer by means of the legitimation and diffusion of a style of life (Gabrielidis 2015: 493). On top of that, initially the media offered the possibility of following up the lives of few people that became very influential in the lives of their audience. On the other hand, these people felt controlled and deprived of privacy from their spectators -the so-called price of fame. But nowadays surveillance technologies are intended for all citizens.

These surveillance technologies allow our patronizing authorities to control a huge amount of private and public information, while putting forward the notion that we are under surveillance for our own sake. The problem is, Bauman signals, that "ubiquitous care 'from the cradle to the grave' could be felt to be oppressive, sometimes infuriatingly so" (2006: 136), and more so when the surveillance 
comes not only from the government but from everyone else. The Internet and social networks have brought about a new model of horizontal surveillance, the "Anfisinóptico", in which all become mutually monitor and monitored (Gabrielidis 2015: 493). The question that arises then is to what extent the lack of privacy and universal control that seems to accompany governmental surveillance can be justified; Bauman himself opens the debate when he explains that "freedom with no security feels no less dreadful and off-putting than security without freedom" (2006: 137). This context may produce a shared feeling of paranoia that can also be found in other contemporary films such as Jason Bourne's trilogy The Bourne Identity (2002), The Bourne Supremacy (2004) and The Bourne Ultimatum (2007), and more recently in Closed Circuit (2013), Captain America: The Winter Soldier (2014) or Furious 7 (2015). In Blackhat, Hathaway initially collaborates with the US government but he ends up being persecuted by it. Bourne's films are paranoid thrillers that share with Blackhat the figure of the isolated individual who has to fight the US government and defend himself against the ever-controlling authorities. A figure that according to Lake embodies "basic American (and basically liberal) values, including the insistence on personal autonomy, the desire for mobility and freedom and the belief that the right reasons for doing things must come from the self, not an external authority" (2013: 13). The aesthetic of the governmental surveillance is shown on the screen of the FBI agents' mobile phones, where the real space of places is shown in its virtual portrait, and Hathaway is another "flow" located thanks to his ankle bracelet. Humans go beyond the borders between the 'space of places' and 'the space of flows' as well as beyond the differentiation between human and machine. They become posthuman or, as Haraway claimed some years ago we had become, explicit cyborgs since our very existence is nowadays unavoidably intermingled with technology:

The inability to divorce everyday life from technology renders the classical humanist framework (in which the human and the inhuman, the natural and the unnatural, are held in binary opposition) obsolete. Rather than continuing to see ourselves as humans, it makes better sense to claim that we are cyborgs. (2000: notes, 148)

Thus the cultural notion of the traditional human being has evolved to the new being conceived as the fusion of a physical body and identity/information, inhabitants of the virtual or at least controlled and located in both spaces at the same time. The former human subject, then, also becomes an object captured and controlled by an increasingly improved surveillance system (Gabrielidis 2015: 481).

During the 9/11 attacks, the US government was apparently overcome by the circumstances and what is more, it proved to be unable to protect its citizens. Many US citizens lost their lives on that fateful day while many others, including 
their relatives, were watching helplessly the events. This caused a general feeling of terrified anguish and the more or less justified belief of being under the spot light, a possible random target for terrorism. Gradually, people of the first world stopped trusting their governments as protectors because they have failed to protect them. As Bauman contends "no longer is the state the omnipotent master of its territory" even though "it remains in charge of law and order inside its territory" (2006: 134). As a consequence of 9/11 events, US and European citizens suffered mass surveillance under governmental control while at the same time they were still possible targets for terrorists. This feeling of being permanently watched, related to the above mentioned notion of the 'Anfisipnoptico', can be inferred in the restaurant scene analyzed below.

The scene is shot with a shaking hand-held camera that suggests real action and the presence of someone else. The camera uses a very subjective perspective as if someone were shooting with his/her mobile phone in a very dark mise-enscene that also recalls the visual style of noir films.

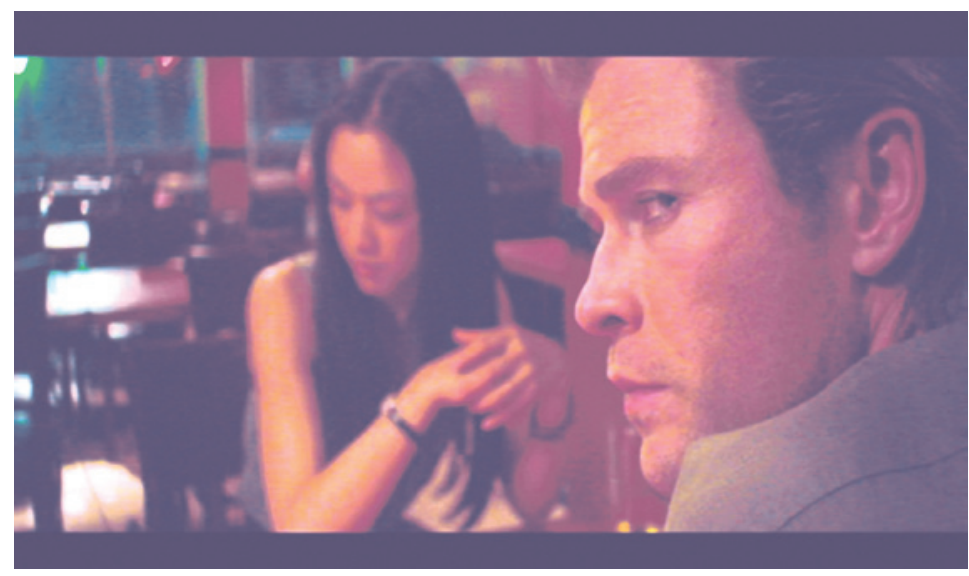

Fig. 1. Screen shot from Blackhat. Restaurant scene.

The gaze is the protagonist's in this scene; shot/reverse shots are used in the dialogue when Hathaway is narrating his past life. Hathaway and Chen Lien Wei Tan - are followed by the shaking camera. Point of view shots and extreme close-ups focus on Hathaway's gaze at the same time as the subjective camera monitors Chen Lien totally unaware and defenseless in the background. Hathaway senses the surveillance and is looking for the eye, technological or human, that is watching them. Finally, he stands up and locates the surveillance camera in the adjoining room. The hidden camera is sending images, flows, information to other 
places. Thus, the scene implies that paranoia may actually exist when threats are not delusions. In the network society risks are real, and not only the threat of terrorism but what Roger Clarke calls "Dataveillance", the transmission of personal and private information from one place to another that creates dangers for the individual such as "wrong identification, blacklisting, denial of redemption, acontextual use of data, unknown accusation and accusers" (1987: np). These flows of information that "constitute the basic thread of our social structure" (Castells 2000: 508) also constitute a real danger for society as a whole. As Clarke contends, it creates a "prevailing climate of suspicion, reduction in self-reliance and self-determination, weakening of society's moral fibre and cohesion" (1987: np), among others. Moreover, as Azcona claims in her analysis of the Bourne films: "the mechanisms that allow people to be mobile are turned into control devices to track, monitor and stop (if necessary) those very mobilities they foster and promote" (2014: 4).

If "space is not a photocopy of society, it is society" (Castells 2000: 441), what are the effects for real space as it becomes controlled, shaped and ruled by the space of flows? Could we infer that the real is dying because of the virtual? Is the "space of places" being gradually absorbed, Castells proposed, by "the space of flows" (2000: 406). What are the implications for individuals? Castells argues that some people think that better connectivity leads to stronger virtual communities but does "the internet favor the development of new communities, virtual communities, or, instead, is it inducing personal isolation, severing people's ties with society, and ultimately with their real world?" (2000: 386). Loneliness, alienation, depression are some of the symptoms of the new citizen in this network society. In virtual realities, very frequently people self-invent their identities; it is not difficult to find profiles of people who share nothing in common with the actual person. People try to improve themselves in the virtual world and change the perception of their identity. Gabrielidis claims that "social networks impose some types of demands, due to their functioning, that force individuals to portray themselves — like this fashionable trend of taking selfies — and their environment. They constantly externalize their thoughts, political ideas, musical tastes and share them online" (2015: 480; my translation). Many people create a virtual but public persona that sometimes develops a totally independent life from the real one and lives and relates in connection with other 'virtual identities'. Sometimes, perhaps often, they will never meet each other in real/bodily life. Image and personal data published on social networking sites become a more conscious and deliberate construction of an identity project than the self that is known, seen and touched in the real world. With greater or lesser fortune, individuals choose the images that they want to project according to their ideas of what their own society understands as an ideal, successful, respectable or worthy model. 
According to Madan Sarup, from a Lacanian perspective the construction of the self is directly related to its relation to society and the others, since human beings are eminently social and "there is no separation between self and society" (1993: 6). Moreover, it is with contact among individuals (the other) and thus with the adoption of language - the means whereby humans communicate - that human beings eventually become social subjects with an illusion of an identity, because "there is no subject independent of language...[and] we all have to represent ourselves in language" (1993: 10). If we extrapolate Lacan's ideas to our present discussion, we find a state of affairs in which social networks, language, and images intermingle to portray individual virtual identities, the result being offered to public scrutiny. In addition, Lacan sees language and desire as notions directly linked; desire is not for him a mere sexual drive but an ontological principle that impels individuals to pursue a sense of wholeness in terms of identity (Sarup 1993: 16). However, for Lacan such endeavor to achieve ontological unity is doomed to failure as there is no coming back to the sense of unity of the imaginary. Mostly in contemporary developed countries, an increasing number of individuals are projecting two split identities, sometimes irreconcilable: one in the real physical world and another virtual one in the "space of flows." Social networks, initially populated by a majority of young people, now are in the process of becoming universalized and inhabited by any kind of individual. To cite but a few examples, in some social web sites, one can find very conservative married men and exemplary fathers in the real world who cast virtual identities as womanizers by uploading bare-chested photos to the Internet to boast about their worked-up muscles; or adult women who adjust to the archetypal patriarchal model of mother-wife at home and pose in the virtual world exposing their bodies in sexy attitudes to collect on-line admirers and a number of 'likes' per day. In a narcissistic way, they build their desired and virtually self-perceived personalities driven by the others' reaction, by the others' eye. In terms of Lacan's 'dialectic of recognition', we acquire the perception of what we are from how the others perceive and respond to us but never forgetting that "we are never going to get a stable image... there is always the possibility of misinterpretation [and]... the stable ego is illusory" (Sarup 1193: 12). Furthermore, it can be argued that egos are much more illusory and unstable within the frantic and expiring dynamics of Internet social networks. This permanent exposition to public judgement inevitably creates personal and identity conflicts because of the desire to offer the best possible image to others and the resulting frustration when the image does not have the expected repercussion or recognition. Visible, even if only as a virtual identity, to the entire World Wide Web, the individual wishes for recognition from the viewers. Lacan's concept of desire, as contended above, is not so much related to sexuality as it is influenced and mainly extracted from the German Idealist philosopher Georg W. Friedrich Hegel: 
Desire, being the revelation of an emptiness, the presence of an absence, is something essentially different from the desired thing. Desire is directed towards another Desire, another greedy emptiness, another "I". Desire is human only if one desires not the body but the Desire of the other; that is to say, if one wants to be 'desired' or, rather, 'recognized' in one's human value. All desire is desire for a value. To desire the Desire of another is really to desire a 'recognition'. (Sarup 1993: 17-18)

In this sense, some individuals construct ideal disembodied identities in the 'space of flows' trying to become the Lacanian 'desire of the Other'. Or as Bracher explains, also from a Lacanian perspective, the individual feels "passive narcissistic desires" of being somehow loved, perceived and noticed by the "Other, which is "the ultimate authority or source of meaning constituted by the Symbolic order and epitomized in our notions of Nature, Society, God, and so on" (1993: 23). The construction of these self-improved virtual identities allows subjects on the one hand to feel good about themselves and find some sense of fulfillment. On the other, they can also be the source of fragmentation and frustration when the successful virtual subject is hardly reconcilable with the physical one still living in the 'space of places'. Identities become more fragmented and complicated, struggling between the real and the expectations and obligations they have imposed upon themselves in virtual life. The possibilities offered by the virtual realm allow individuals to create new, different and improved personalities, the type of person they cannot be in the physical realm, and the obscure villain in Blackhat, Sadak - Yorick van Wageningen - constitutes a good example of how a bland individual in real life grows up to be a powerful villain in the virtual one.

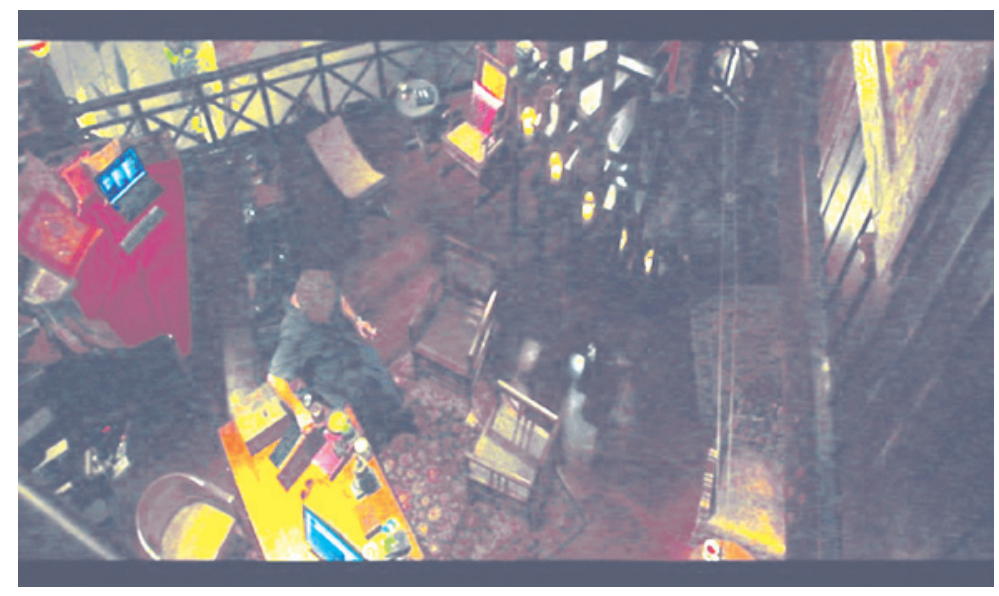

Figure 2. Screenshot from Blackhat (2015). The villain in his cellar. 
This very brief shot of the villain is hardly noticeable at the beginning of the film, when the malware is extending through cables and circuits. He is shot from a high angle and he seems Mr. Nobody, invisible, hidden in a dark room with classical furniture and wooden walls like a modern phantom of the opera. The angle of the camera suggests that he is in a cellar, insignificant, indistinguishable in the darkness. He can be any of those people who spend their lives in front of a computer screen. Sadak is not even a computer genius, as spectators learn afterwards he has only modified the malware downloaded from the web, but he is still a real threat. He is able to destroy the most beautiful landscapes and kill people because he has the power to control the flows. He seems narcissistic and probably suffering from delusions of grandeur because he is someone in the net and nobody in the real world. The film epitomizes Sadak as a new type of criminal much more difficult to control in our contemporary cultural imaginary. He embodies the most feared side of the network society together with terrorism and radicalism. Sadak is a person without conscience or moral principles; he makes the most of the lack of control in the web and does not hesitate to destroy the real world where he probably does not fit. Using Beck's words, he could be described as an uncontrollable risk de-bounded in its social dimension.

Furthermore, in the new space of flows the individual identity can be not only pretended, but also supplanted. Personal identity now consists of data recorded, information travelling through the net. However, this is not a recent phenomenon as identity has always been linked to information and data. Katherine Hayles states that "we are essentially informational patterns" (1999: 22). Whether cyborgs, as Haraway calls us, or as posthuman beings, it is undeniable that in spite of being physical bodies living in the 'space of places,' part of our actual identity is also made by information already kept outside our physical bodies, in the web memory. The Internet, as Gabrielidis describes, "functions collecting images and personal data, that in the case of the average citizen initially were surely intended to be shared only with friends, but eventually, this information can become the source of their own surveillance and the support of the power exercised over them" (2015: 487; my translation). Nevertheless, as Gabrielidis herself acknowledges, in our time "being completely removed from this visibility regime has a dark side, it can be the real and concrete disappearance of a person" (2015: 491; my translation). One does not exist unless his/her personal data is not stored and used in the virtual world. Moreover, whoever can get your information may also appropriate your identity. Identity has become something out of the individual control, based and supported by the virtual. This is one of the examples of the threat that Clarke's concept of Dataveillance involves. Sometimes the only thing that protects our personal information and money is a password or a pin, as Blackhat also 
warns. Hathaway himself supplants a high-ranking FBI officer's identity in order to achieve the Black Widow, a security program he needs. He writes an email pretending to be this officer, Ben Hitchens, and gets the password which allows him to take control of the software. This time it is 'for a good cause' but the danger of losing our identity and possessions is another source of worry and paranoia in our present network society; again paraphrasing Beck, an uncontrollable risk de-bounded, this time in its spatial/ontological dimension.

Finally, the traditional heroic pattern rules again. The criminal is killed by the hero and Hathaway escapes with the girl. The film ends in an airport, a place associated with constant mobility, quintessentially the place where people move, and nobody stays. Both, Hathaway and Chen Lien have become flows in the real world because they will not be allowed to remain in a single place for a long time. They should be vigilant because now they are in a bigger prison than that in which Hathaway was at the beginning. The Earth is a 'shrinking world' that has become "an increasing interconnected space in which distances can be transcended at supersonic speeds or even at the push of a button" (Kirsch 1995: 529). Our world is now at the same time an attainable space and, in consequence, a totally monitored place, not only by technological devices but by the huge device constituted by billions of eyes watching our virtual identities. Hathaway and Chen Lien may have money now, but it is in the virtual space, it is data, flows of information, and it can be discovered and cut at any moment. The two main points I have discussed in this paper are present in the film's ending: surveillance and flows. Hathaway and Chen Lien walk by one of the Airport corridors surrounded by flows of unknown people. People are moving in different directions, but all of them are being watched through surveillance cameras, their freedom and mobility are fragile. At any time Hathaway and Chen Lien can be recognized and stopped. Ultimately, they cannot escape, because the network's tentacles can reach every place, the entire world is accessible for them. The Earth, as the first scene showed, belongs to the net.

The spread of new technologies has changed our perception of the world. Nowadays the real and the virtual overlap and influence each other. In our network society, the increasing importance of the virtual over the real seems to be changing very quickly the way we (post)humans live, behave and move, in short, they are transforming our society. Blackhat is a good example of the dangers brought about by this negotiation existing between the real and the virtual. Our real ontology, the physical one, seems to be losing ground in the confrontation with the virtual one. The real is ruled, controlled and invaded by the virtual. Furthermore, this instant communication of people, goods and money which would have the potential to change the world for the better is perceived somehow like a threat. It entitles governments with the self-proclaimed right to control everyone, because new 
menaces are diffuse and untraceable and in the alleged interest of the common good no one is exempt from the vigilant eyes. This feeling of permanent movement, connection, fragmentation, and self-invention of identities comes as a result of the possibilities that new technologies have brought about. The interpenetration and the blurring of the limits between physical identities and virtual ones, together with the idea of living in a world in which there is no escape and in which we are always the object of surveillance on the part of governments but also due to our voluntary exhibition on the World Wide Web are, beyond its mere narrative adventure, main concerns in Blackhat. May be structurally Michael Mann's is not a flawless film, but it offers a serious warning about the dangers of our present quest for new virtual identities, thus surpassing mere market expectations.

\section{REFERENCES}

Azcona, M. M. 2015. "Don't Stop Me Now': Mobility and Cosmopolitanism in the Bourne Saga”. Mobilities. Taylor \& Francis Online. http://www.tandfonline.com/ doi/abs/10.1080/17450101.2014.957014?journalCode=rmob20\#.VoGJrCeTmBI (Accessed 20 Dec. 2015).

Bauman, Z. 1998. Globalization: The Human Consequences. New York: Columbia University Press.

Bauman, Z. 2006. Liquid Fear. Cambridge: Polity Press.

Beck, U. 2002. "The Terrorist Threat World Risk Society Revisited." Theory, Culture E Society 19 (4): 39-55.

Bracher, M. 1993. Lacan, Discourse and Social Change: A Psychoanalytic Culture Criticism. Ithaca and London: Cornell University Press.

Bradshaw, P. 2015. "Blackhat review - Mostly Ridiculous Cyber-Thriller from Michael Mann”. The Guardian. http://www.theguardian.com/film/2015/ feb/19/blackhat-review-michael-mann (Accessed 3 Nov. 2015).

Castells, M. 2000. The Rise of the Network Society: Vol. 1. Oxford: Blackwell Publishing.

Clarke, R. 1987. "Information, Technology and Dataveillance". Roger Clarke's Web-Site. Ed. J. Fendrich. Association for Computing Machinery Inc. http:// rogerclarke.com/DV/CACM88.html (Accessed 28 Dec. 2015).

Foucault, M. 1977. Discipline and Punish: The Birth of the Prison. New York: Vintage.

Gabrielidis, M. A. L. 2015. "Visibility and Surveillance Regime in the Age of Digital Identity". Teknokultura 12 (3): 473-499. 
Haraway, D. J. 2000. "A Cyborg Manifesto: Science, Technology, And SocialistFeminism in the Late Twentieth Century". Posthumanism. Ed. Neil Badmington. Houndmills, Basingstoke, Hampshire and New York: Palgrave. 69-84.

Hayles, N. K. 1999. How We Became Posthuman: Virtual Bodies in Cybernetics, Literature, and Informatics. Chicago: University of Chicago Press.

Kirsch, S. 1995. "The Incredible Shrinking World? Technology and the Production of Space" Environment and Planning D (13): 529-555.

Lacan, J. 1995. Seminar XI (1964). The Four Fundamental Concepts of Psychoanalysis. New York: State University New York Press.

Lake, C. B. 2013. Prophets of the Posthuman: American Fiction, Biotechnology, and the Ethics of Personhood. Indiana: University of Notre Dame Press.

Lakoff, G. 2006. "Thinking Points: Communicating Our American Values and Vision". Faculty Web Sites at the University of Virginia. http://faculty.virginia.edu (Accessed 25 March 2015).

Macnab, G. 2015. "Blackhat, film review: Chris Hemsworth Stars in an OldFashioned Thriller with a Bit of Byte". Independent. http://www.independent. co.uk/arts-entertainment/films/reviews/blackhat-film-review-chris-hemsworthstars-in-an-old-fashioned-thriller-with-a-bit-of-byte-10057835.html (Accessed 3 Nov. 2015).

O'Sullivan, M. 2015. "Blackhat' movie review: A Hacker Saves the World, a Reviewer Saves Your Time". The Washington Post. https://www.washingtonpost. com/goingoutguide/movies/blackhat-movie-review-a-hacker-saves-theworld-a-reviewer-saves-your-time/2015/01/14/7d181804-9b68-11e4-a7ee526210d665b4_story.html (Accessed 3 Nov. 2015).

Sarup, M. 1993. Introductory Guide to Post-Structuralism and Postmodernism. New York, London, Toronto, Sydney, Tokyo and Singapur: Harvester Wheatsheaf.

\section{FILMS CITED}

Blackhat (Michael Mann 2015)

Captain America (Anthony and Joe Russo 2014)

Closed Circuit (John Crowley 2013)

Furious 7 (James Wan 2015)

The Bourne Identity (Doug Liman 2002)

The Bourne Supremacy (Paul Greengrass 2004)

The Bourne Ultimatum (Paul Greengrass 2007). 